\title{
THE REGAINING TERRITORY OF THE OJIBWA TRIBE IN LOUISE ERDRICH'S THE BIRCHBARK HOUSE BOOK SERIES
}

\author{
Ramadhina Ulfa Nuristama \\ ramadhinanuristama@gmail.com
}

\begin{abstract}
Native American people had been experienced in confronting the white people. One of their experiences in confronting the white people is written in the Louise Erdrich's literary works, an Ojibwa author. Native American authors have different point of view in telling about Native Americans because they and their ancestors have bitter experiences in dealing with the white people, especially the Ojibwa tribe's experiences living in the America where other Native American tribes cannot survive their tribes. This study focuses on the struggles of the Ojibwa people in getting their territory and the reasons why the Ojibwa people try so hard in keeping their territory.

This study uses post-nationalist American Studies paradigm which is supported by Historicism theory in the analysis. The method used is qualitative method related to literature study by using the five books of The Birchbark House book series as the primary data of this study. There are several conclusions based on the analysis of the data. The Ojibwa people are able to maintain their tribal presence in America against the white people. They can defend their tribe by using their intellectual, courage, and self-confidence. As for the reasons they prefer to choose their own way in getting territory because of several factors such as beliefs, relatives, and natural conditions of the land.
\end{abstract}

Keywords: Post-national, Indian Territory, Native American, Ojibwa

\section{Introduction}

The arrival of the white people in the Native American land made the Native American people had to face many wars and battles to defend their territory. Many of them were lost and not a few from them won the battles and wars in defending their land. The white people forced them to leave their land and they had to cede their land. Some of the Native American people chose to move from their former homes and try to find the new ones. Indeed, the coming of the white people made their life worse even worst. It could be said that they were the hosts of the land, but they were driven out from their own homes.

Based on these pathetic experiences, there are a lot of authors who try to portray and figure it out through literary works. The descendants of the Native American who had been put into boarding school and learned to read and write, try to tell the story of their ancestors experiences in facing the white people. Louise Erdrich is an Ojibwa writer of novels, poetry, and 
children's books featuring Native American characters and settings. She is a part of the Turtle Mountain Band of Chippewa Indians, one of the Anishinabe bands which is also known as Ojibwa, Ojibwe, or Ojibway (Beidler and Barton, 1999: 1). She is also the owner of Birchbark Books, a small independent bookstore in Minneapolis that focuses on Native American literature and the Native community in the Twin Cities. Like all Native American writers, Erdrich shares the assumption that history holds the key to understanding Native American life. According to Louis Owens in Lee Schweninger's book entitled Listening to the Land:

Native American writers are offering a way of looking at the world that is new to western culture. It is a holistic, ecological perspective, one that places essential value upon the totality of existence, making humanity equal to all elements but superior to none and giving humankind crucial responsibility for the care of the world we inhabit (2008: 116).

It means that the Native American writers give different point of view rather than the European American authors who write about Native American literary works. It is because they do not experience the Native American experience itself as well as the Native American authors. Ojibwa writer,
Louise Erdrich, contends that the task of Native American authors writing about place is different from European American authors because Native American writers must tell the stories of contemporary survivors and in all this; there is always the land.

The Birchbark House book series by Louise Erdrich consists of five books entitled The Birchbark House (1999), The Game of Silence (2005), The Porcupine Year (2008), Chickadee (2012), and Makoons (2016). The story follows the life of Omakayas and her Ojibwa community beginning in 1847 near present-day Lake Superior. But, the life of the Ojibwa community changed because of the coming of the white people in their land. Their lives were getting worse because of the new comers. They lost many things. However, even in the worst condition, they had to defend and preserve their tribe. Because of their struggles, the Ojibwa tribe still exists until now in America.

The contact of the white people and Ojibwa tribe in their territory triggers the annexation between them in fighting for the territory. Since the white people brought the law form the Europe which had been established, they wanted to own the Native American's lands as well as they thought that this land is a free land. It 
was different with the Native American's principle in treating and owning their land. In the five books that this study used, they tell about the journey of the Ojibwa tribe before the white people came to their land and when they came to their land. There were several changes in treating and owning their land and territory because of the arrival of the white people.

Besides the differences on the issue of land ownership, the Ojibwa tribe has an obligation to survive in the land of America for their descendants. Land as their territory means a lot for the Ojibwa. They live in the land and also fulfill their daily needs by the natural resources which exist in their land. Since their struggles in facing the coming of the white people in their territory, the Ojibwa tribe has been done many things in defending their territory. Moreover, the territory means a lot for the life of the Ojibwa tribe and their future generations. Based on this consideration, this study reveals how the Ojibwa tribe gets their land back and maintains their existence and elaborates the reasons which make the Ojibwa tribe gets their land back.

\section{Methodology}

This study is under the PostNationalist American Studies paradigm since this study questions the dominance of the United States. This paradigm provides an opportunity to view multicultural such as racial and ethnic groups in America that have been marginalized by the American Exceptionalism's point of view. “American Studies practitioners could no longer sustain the fiction that Americans "shared" a national character based on common experiences" (Rowe, 2000: 5). It means that the racial and ethnic groups which have different experience in living in America can be viewed as the part of America itself. Then, it gives chance for the marginalized people such as the Ojibwa people to show up their experience as the part of the America.

In the scope of American Studies, we can trace and analyze the phenomena which have been occurred in the American history timeline. History is a substantial aspect to be dealt with for the past. Likewise, the past events must be strongly correlated with the principal data for this study. According to Bennet and Royle who state that literary works can help us to understand the time in which they are set: realist texts in particular provide imaginative representations of specific historical moments, events or periods (2004: 113). It tends to assume that literary 
texts provide undistorted 'reflections' of their time. The Birchbark House book series tells the series of events of the Ojibwa tribe in finding their new home in order to maintain their tribe until now. Then, they also assume that it is possible for our knowledge of both historical events and literary texts to be detached and objective, outside the forces of history (Bennet and Royle, 2004: 115). Thus, the literary works and historical narratives are related each other in making better understanding about historical events of people which are studied in this study is the Ojibwa people.

The primary data of this study is The Birchbark House book series which consists of five books entitled The Birchbark House (1999), The Game of Silence (2005), The Porcupine Year (2008), Chickadee (2012), and Makoons (2016). There are three reasons underlying the selection of those books as the primary data. The first reason is those books portray the struggle of the Ojibwa tribe in the land of America. Even though they are the indigenous people of the America, but the coming of the white people have made them moving from their own land and finding new homes. The second reason is The Birchbark House book series tell how the Ojibwa tribe struggles for their land in
America. It is very challenging since it is told in the kind of book series, not only in the one literary work. The last reason underlying the selection of those books is the fact that those books are written by the Ojibwa author, Louise Erdrich. Even though there are several authors who are the descendants of the Ojibwa tribe, but Louise Erdrich as the Ojibwa author has produced a lot of works which have garnered numerous awards.

Then, in analyzing the Ojibwa tribe's journey in America, it is suitable that looks on their historical background how and why they can maintain their tribe until now even though many forces forced them to leave their land. It is supported by Payne and Barbera:

Historicism is the theory and practices which privileges historical explanation on the grounds that ideas, values, and practices - indeed all things human - are discrete products of particular culture rather than transhistorical manifestations of essential, universal features of human identity and society (2010: 332).

That is clearly that the journey of the Ojibwa people in the America can be explained historically since their existence is the product of particular culture which does not exist immediately. They have maintained it in a long period to gain their land as their territory where they can 
maintain their existence for their future generations.

\section{Discussion}

In discussing the struggles of the Ojibwa tribe in getting new home and the reasons why they choose to move, it is related to their historical background which comes along with their way in confronting the white people. The Ojibwa tribe gets a lot of pressures from the white people to leave their land and force them to move westward, to the reservation. In this case, the Ojibwa tribe is also told that they do not obey the white people to move westward to the reservation. They know that reservation is not a good place for them and their descendants. They prefer to look for new place to live and to maintain their traditions and cultures.

\section{The Struggles}

Native American people are considered as savage and uncivilized in the white people's point of view. This is because the Native American people do not have the same educational system as the whites have. They do not have school buildings and school uniforms.

They believed that one of the greatest barriers to assimilation was the Indians' attachment to tribal life. By separating Native American children from their kinspeople and sending them to boarding schools, preferably located far from their homes and communities, it was hoped that assimilation would be finally achieved (Hirschfelder, 2000: 129).

It shows that the white people want to kill their aboriginal cultures in the name of civilizing them. They think that the Ojibwa people who never had education system like them are not kind of intellectual people. However, they have their own way to educate their children and their grandchildren. They use oral traditions.

Then, when the white people come to their land and set up school, Ojibwa children are forced to enter the school. The purpose of the white people is to abolish their aboriginal traditions and cultures. They put their cultural values in the school curriculum. In fact, they also teach Christian values in the school. However, because the Ojibwa children are intellectual people, when they return from the school, they do not really practice what is taught in the school, especially in the cultural and religious sections which are not fit to theirs. They only practice how to read and write in English. It is important for them to understand what the white people wrote in treaties that they have to sign. 
The Ojibwe relied on memory. They repeated stories, songs, the words to promises and treaties. Everyone memorized all that was important. Although people scratched elaborate signs on birchbark and rolled them into scrolls, they relied on memory to go with the marks. Memory was Ojibwe writing. Things were not forgotten that way. Something about the black marks had gone wrong, Omakayas knew that. The black marks promised one thing, but the chimookomanag wanted to break that promise (Erdrich, The Game of Silence, 2005: 20).

In the quotation above, it shows that the Ojibwa people have a good memory. When they are able to read what is written in the treaty, they realize that the white people revoke their own promises which they make by themselves in the treaty.

The Ojibwa people decide to send their children to the white people's school to learn English. It will make them easier to understand everything that is written in the treaties and make them easily communicate with the white people. If they do not understand English, they will trap and plunge into the confusion in understanding the treaties. The Ojibwa people "must learn to read, and to write the white man's language. If they do not do this, everything will be stolen from them" (Erdrich, Chickadee, 2012: 101). This is true because the treaties they have to sign are written in English, thus if they do not know the content of the treaties, they will lose everything they have.

Ojibwa people never destroy nature and everything that is in the nature. Instead, they take great care of the nature in which they live in. They live in the land and can live by making use of everything in the nature. Thus, if they do not take care of that nature, just as they ruin their own lives. The things like these that never come to the white people's mind. They destroy the natural ecosystem to fulfill their living needs. They cut down trees in the forest to make settlements. The animals that live in the forest become homeless and become extinct.

Since they believe that their land as Mother Earth, they treat their land as well as they treat their mother. Mother gives everything what her children needed vice versa her children will give respect towards their mother. This connection which makes the Ojibwa people take very good care to their land and the nature in it. Without regarding age, gender, and position in the daily life, the whole society of the Ojibwa tribe participate in maintaining nature and the land which they occupy. According to Keraf, the Ojibwa people's behavior in treating land and nature is a form of their concern for nature 
because they do not distinguish the position of human being and non-human being and it is called ecocentrism. Ecocentrism focuses on the whole that exists on earth, whether living or not. Thus, they are very conserving the nature and its contents as a form of their moral responsibility to nature since humans and nature depend on each other. Humans need nature for their survival, thus that when they take care of the nature well, they will gain goodness from the nature itself (2010: 48).

Although living in the nature does not always run well, the Ojibwa people never try to destroy the nature itself. As written in the quotation below:

"If something on the trail goes wrong, a tree falls across, a pole breaks, then we fix it. We depend on those who went before us to do the same. Once, I explained this to Nokomis. Know what she said?" "What?"

"She said that was how the world should work. We should fix what we break in this world for the ones who come next, our children" (Erdrich, Chickadee, 2012: 180).

The Ojibwa predecessors do the same thing as well as the Ojibwa people now. They keep the nature very well for their future generations. It will be taught from generation to generation inherently. Thus, even now they will keep the nature where they live in. Even, when any part of the nature is broken, they will fix it. They will plant trees to preserve the nature and save their future generations. It means that the Ojibwa people do really care for their future life and their future generations.

In the other side, the white people bring the laws from Europe including law about land ownership. When the Ojibwa tribe does not have a written rule that states this land is theirs, the white people assume that this land is free and they can own it. They also assume that nature and its contents can be utilized as much as possible for their needs as a form of moral responsibility towards human being rather than to the nature itself (Keraf, 2010: 47). This point of view does not make the Ojibwa people cede their land easily to the white people. They fight in many wars until finally the white people offer diplomacy to them by signing contracts and treaties which state that they hand over their land, they will get foods and goods from the white people. It is just promise that the white people never fulfill it.

Moreover, the white people attempt to damage the Ojibwa people's mind and moral. They introduce alcohol into their life:

"We hasten our own destruction sometimes," said Deydey. "The 
traders offer their 'milk,' which is that crazy stuff. Alcohol. Ishkodewaaboo. The liquid that burns."

"I have seen men kill the ones they love,” said Quill, shaking his head. "There are some who cannot resist it. I, too, have drunk it. But now I stay clear. Too many bad things happen.” "That is our enemy too, that trader's 'milk,"” said Deydey (Erdrich, Makoons, 2016: 88).

The Ojibwa people are aware that alcohol is also their enemy which makes them unconsciously do everything what the white people ask for. Thus, knowing that alcohol is dangerous drinking, the Ojibwa people with their intelligence avoid it.

They are not only wise in avoiding alcohol, but the Ojibwa people also have good resistance towards diseases which are brought by the white people such as fever and smallpox. Yet, it can be denied that they also lost several parts of their relatives because of those diseases. The ones who can survive through tough times are those who are brave and strong people. It proves that they are strong nation in the America. Though, they know that they white people are the great threat and enemy in their whole lives, but they will face it like a man. As the quotation below:

"But the biggest threat is the people who gobble the land. They are coming. They are white people," said Deydey.
"It is the treaty makers," said Quill, "those who do not keep their promises. I hear Little Shell speaking of the Great White Father - our president. He doesn't trust that one. We have seen what happened in Mne Sota. We have seen what happened to the Dakota” (Erdrich, Makoons, 2016: 87).

It shows that their peaceful lives are disrupted by the coming of the white people and they do the same to the other tribes. Many innocent people have to live in suffer of hunger and homeless. Dakota is their neighbor and they know each other since when they involve war parties long time ago. Thus, everything that happens to them, the Ojibwa people will hear the news immediately. Moreover, after both of them deal with peaceful agreement, they trade each other. Then, no wonder that the Ojibwa people know the condition of the Dakota people when they are attacked by the white people, their land is seized and many of their people suffer from hunger and homeless.

Living in the difficulties, the Ojibwa people must be able to survive. They were born as a great warrior. They have a strong confidence which gives them a great spirit. As in the quotation below:

Remembered Grandma's advice: "Take their ways if you need them," she said, "but don't forget your own. You are Anishinabe. Your mother 
and your grandmother are wolf clan people. Don't forget. Also, you sweat-bath yourself clean everyday, even jump in the freezing lake, a thing that the chimookomanug do not do. My girl, don't become like them" (Erdrich, The Birchbark House, 1999: 110).

Their parents teach them how to live in this world well. Though the white people consider they are savage and uncivilized, but they are actually kind of civilized people. Even, they keep the cleanliness for themselves. Since they are so close to the nature and their clothes are also made of the animal furs which they get from the nature make them look shabby and dirty in the white people's mind. These two different arguments trigger quarrels between the white people and the Ojibwa people. However, the Ojibwa tribe never gives up immediately since the white people came to their land. They try hardly to maintain their tribe, including the people and the culture. Then, by using their intelligence, courage, and selfconfidence, the Ojibwa tribe is defined as one of the largest and most powerful tribes in North America (Waldman, 2006: 64). It is explained that they still exist until now in North America.

\section{The Reasons}

In finding new home, the Ojibwa people do not immediately move to other place. They also have a number of considerations, such as beliefs, relatives, and the condition of the land where they will live in. These things are crucial for them since they have to survive their lives, their cultures, and their future generations. They used to live in their own way of life will maintain their traditions for their children and their grandchildren.

\section{Belief}

According to Densmore, it is a belief of the Ojibwa that by possessing some representations of a dream subject, someone could at any time secure by its protection, guidance, and assistance (1979: 79). By having this belief, they become confident and sure in living and enjoying their lives. When they get dream, they believe that that dream brings guidance for them to face their lives. The spirits are from their ancestors who died and spirits of the animals that they considered as sacred animals. They believe that the spirits live with them and stay in their land before the white people came to their land. They serve to protect and guide the Ojibwa people in living their lives. Whenever the Ojibwa people get into trouble, the spirits 
that they believe in will come to help them. The way the spirits help the Ojibwa people can pass by dream or come to them directly through any kind of medium such as animals. However, not all of the Ojibwa people can get this kind of vision. There only certain people who can get this kind of vision, it can be said the chosen people. It is supported by Norrgard:

In Ojibwa culture, individuals had deeply personal and spiritual relationships with specific animals that would assist and provide them with guidance throughout their lives. These alliances came through dreams and encounters with animals as well as having a name or being part of a patrilineal clan associated with a particular animal (2014: 45).

Besides, in the Ojibwa society, there is a Midewiwin (Grand Medicine Society). They are people who are given more ability to cure illness and also get the vision of the spirits. They highly appreciate to the existence of the spirits in their lives because they get many things from the spirits, such as they are given a vision that living in the west is not as well as their lives in the northeast. "West is where the spirits of the dead walk. If the whites keep chasing us west, we'll end up in the land of the spirits" (Erdrich, The Birchbark House, 1999: 79). It makes the Ojibwa people believe that the west is not good place for them. In the quotation, it is stated that west is the place of the dead walk spirits. The dead walk here means the other tribal people who have already lived in the west, in the reservation, and they are like dead people who can walk. It is because their lives suffer from hunger and desperate for losing their homeland and their family members. For eating, they have to wait for the white people give them food supplies since they can no longer hunt in the area where the animals are so limited. Living by depending on the white people is not good at all since they only give uncertainty things in the life of the Native American people, such as they do not know when they are free from hunger and so on. This consideration causes the Ojibwa people not to rely on their lives for the white people because they cannot be trusted in keeping their promises.

\section{Relatives}

In the social life, the Ojibwa people live communally with their relatives. They often hold gathering camps like a sugar camp with their fellows and relatives. However, the arrival of the white people made them scattered because they escape in the chaotic situation when the white people attacked their land and burned their 
homes, their wigwams. They run away in wherever they can as long as they do not meet the white people anymore. Thus, some of them run westward and some of them go to the north. They cannot move to the east since the white people came from the east and they occupied the land in the east. Many of the Ojibwa people who know the life in the reservation is not as good as the promise of the white people do not move westward. Instead, they move northward. "People were packing up to move on, to live on the mainland with relatives, for the end of the winter was harsh" (Erdrich, The Game of Silence, 2005: 201).

Living with the relatives can make the Ojibwa people easier to communicate because they speak the same language. Since there are so many Native American tribes in America that have their own aboriginal languages, it means that each of tribe will speak different languages. They will get into trouble in communicating with each other if they live with the other tribes which speak different languages. Then, living with their relatives can facilitate them in communicating each other.

Besides, every Native American tribe has their own traditional cultures. They will be easier in maintaining and performing their traditional cultures, such as sacred rituals and ceremonies with the people who also do the same things as well them which is meant that their relatives, the people who come from the same ancestors. Moreover, they often perform such kind of rituals and ceremonies to ask for the spirits' helps. It does not work if the Ojibwa people want to do the sacred rituals with the others who come from the other tribes with different beliefs. They prefer to live with their relatives since they can preserve their traditions.

The rituals and sacred ceremonies are the part of their cultures. They have to defend the heritages from their ancestors. The existence of the people have the same culture and do the traditions are important in maintaining and preserving the existence of the tribe itself. It is because they themselves who do those kinds of traditions although the other Native American people also do rituals and ceremonies, but they have their own ways in performing their traditions. Moreover, they believe in different spirits. They cannot worship the spirits that they do not believe in if they have to live with the other people who worship different spirits. In the new place, although the place is not much different from their homeland, they 
need to adapt to their new environment. As in the quotation below:

The Algonkians migrated to the Great Lakes region around AD 1200, were they gradually split into groups: Ottawa, Cree, Potawatomi, Menomini, and Ojibwe. According to Stanley Murray, sometime around 1600 the Ojibwe group began moving westward and split again into groups occupying areas around Lake Superior (Jacobs, 2004: 24).

In the quotation above, it is explained that the Algonquian people are separated into several groups. Even though they come from the same origin, but they live in several places in the same region. Migration makes the Ojibwa people separated into several bands. In The Birchbark House book series mainly talk about The Turtle Mountain Band of Chippewas. However, they prefer call themselves as Anishinabe or Ojibwa which is their aboriginal name rather than Chippewa which is given by the U.S. government.

\section{Condition of the Nature}

Furthermore, in the journey of finding new home, the Ojibwa people consider about the land that they live in. It has power towards them since it has energy to strengthen them in living their lives. According Leland Bell in Smith's book entitled The Island of the Anishinaabeg, "The energy exists within the land - the North American continent. It exists within human culture - the Ojibwa's origins, history, present and destiny. It exists within the Ojibwa's spiritual teachings which sustain him/her on the earth” (1995: 191). They are very appreciative towards their land, they respect their land and even their land is so sacred and significant for their lives.

In preserving their land, the Ojibwa does not necessarily use all the resources in the nature. They only use natural resources which they need since they are not greedy in using the natural resources. They think about their descendants who will occupy their land. Knowledge about treating the nature is obtained without going through the education that is already well-established. They recognize the relationship between human beings with nonhuman beings like earth, water, air, animals, and plants. Based on this knowledge, they know that they have to be respectful towards the other parts of the nature which live harmony among them. They get such kind of knowledge by oral tradition. Their ancestors taught their descendants from the storytelling. They are taught how the earth was formed, how to 
treat the nature, and so on. As Churchill stated that:

Human beings are free - indeed, encouraged - to develop our innate capabilities, but only in ways that do not infringe upon other elements called "relations," in the fullest dialectical sense of the word - of nature. Any activity going beyond this is considered as "imbalance," a transgression, and is strictly prohibited (2002: 17).

They preserve their soil, thus if there is an activity which can damage the preservation of the land and the nature, it is considered as an offense. They do not take anything too much from the nature, only take what they need.

The land and natural condition in the north has several similarities with their homeland because they belong to the subarctic area. They will be easily to adapt in the land where they will start their new life. They also meet the Métis who are the descendants of the Ojibwa and French. They learn how to hunt in the new place by using cart from the Métis which they never used before in their homeland. However, since the Ojibwa people are kind of intelligence people, they can quickly adapt to hunt using new technique. They begin their new life and they will preserve their cultures of their ancestral heritage for their people, for their future generations.

\section{Conclusion}

In the five books of The Birchbark House book series, it shows that the Ojibwa tribe can defend their tribe because they fight against the white people who came to their land. Even though they cannot defend their homeland, they have their own territory in the end that they manage by themselves. In getting their own territory again, they have to use genius steps, such as they send their children to the mission school in order to learning English.

The Ojibwa people hope that their future generations can speak and write in English. Then, they will not be fooled by the white people as well what they had done to their ancestors. Besides, the Ojibwa tribe bravely fights the white people who want to own their land until they offer the Ojibwa people diplomacy by signing treaties. They are not afraid in dealing with the white people who have more sophisticated weapons than theirs. Instead, the white people are afraid of the Ojibwa people that make them offering diplomacy to the Ojibwa people and promising them many things.

They lost their homeland because the white people trap them to sign the treaties. Then, they choose to move northward. Their journey to the north is based on 
several reasons, such as because of their beliefs, their relatives, and also the natural condition in the north. The Ojibwa people believe in spirits. They believe that the spirits live in the same nature and land with them to preserve the nature. The arrival of the white people destroy the nature as well as where the spirits live in. The Ojibwa people believe that the spirits instruct them not to go westward. Then, they follow the instruction to go to the north. By having strong belief in Great Spirit which they called Gizhe Manido, they can maintain the existence of their tribe until now. This is because they believe that the Great Spirit always leads them to live their life, even it is the most essential thing which makes them move northward.

\section{References}

Beidler, Peter G. and Gay Barton. 1999. A Reader's Guide to the Novels of Louise Erdrich. University of Missouri Press.

Bennet, Andrew and Nicholas Royle. 2004. Introduction to Literature, Criticism and Theory, Third Edition. Pearson Education Limited.

Churchill, Ward. 2002. Struggle for the Land: Native North American Resistance to Genocide, Ecocide, and Colonization. City Lights Books.
Densmore, Frances. 1979. Chippewa Customs. Minnesota Historical Society Press.

Erdrich, Louise. 1999. The Birchbark House. United States of America: HarperCollins Publishers.

Silence. United States of America:
HarperCollins Publishers.
2008. The Porcupine Year.
United States of America:
HarperCollins Publishers.

- 2012. Chickadee. United States of America: HarperCollins Publishers.

States of America: HarperCollins Publishers.

Hirschfelder, Arlen B. 2000. Native Americans. New York: Dorling Kindersley Publishing, Inc.

Jacobs, Connie A., Greg Sarris, David T. McNab, et all. 2004. Approaches to Teaching the Works of Louise Erdrich. New York: Modern Language Association of America.

Keraf, Alexander Sonny. 2010. Etika Lingkungan Hidup. Jakarta: PT. Kompas Media Nusantara.

Norrgard, Chantal. 2014. Seasons of Change Labor, Treaty Rights, and Ojibwe Nationhood. The University of North Carolina Press.

Payne, Michael and Jessica Rae Barbera. 2010. A Dictionary of Cultural and Critical Theory, Second Edition. Blackwell Publishing Ltd.

Rowe, John Carlos. 2000. Post-Nationalist American Studies. University of California Press. 
Schweninger, Lee. 2008. Listening to the Land: Native American Literary Smith, Theresa S. 1995. The Island of the Anishinaabeg. Moscow: U of Idaho P.

Waldman, Garl. 2006. Encyclopedia of Native American Tribes. Third
Responses to the Landscape. The University of Georgia Press.

Edition. New York: Library of Congress Cataloging-in-Publication Data. 